\title{
ENTRE EL GESTO Y LA PERFORMANCE. UNA LECTURA DE LA ESCRIBANA DEL VIENTO DE ANA TERESA TORRES
}

\section{ENTRE O GESTO E A PERFORMANCE. UMA LEITURA DE LA}

ESCRIBANA DEL VIENTO DE ANA TERESA TORRES

Jesús Oneiver Arellano Pérez*

RESUMEN: En este artículo pretendo analizar cómo $L a$ escribana del viento (2013) se configura a partir de un conjunto de elementos que apuntan a modificar la perspectiva estética que se tiene del pasado y en consecuencia la visión que se tiene de la historia. La novela se interpretará bajo la idea de "narrativa performática". Este análisis estará organizado a partir de tres ejes específicos: primero, la historia contada desde y por los sujetos minorizados; segundo, el cuerpo como agente configurador de los acontecimientos narrados; y, por último, la recurrencia a la imagen y al gesto para posicionar el discurso histórico en la esfera de las emociones. El montaje en la novela historico en la entera de muestra una insistencia en la imagen, el texto se teatraliza, los discursos de los personajes se convierten en gestos y las múltiples posibilidades interpretativas no sólo ponen en diálogo el presente con el pasado, sino que dan cuenta de una pulsión por lo contemporáneo.

PALABRAS CLAVE: Novela histórica; literatura venezolana; performance; cuerpo. *a.j.oneiver@gmail.com

Doctorando en Letras en la Universidade Federal de Minas Gerais. Magister Scientiae en Literatura Iberoamericana y Licenciado en Letras Hispanoamericanas por la Universidad de Los Andes (Venezuela).

RESUMO: Neste artigo pretendo analisar como La escribana de/ viento (2013) configura-se a partir de um conjunto de elementos que têm como alvo modificar a perspectiva estética que se tem do passado e que, por conseguinte, propõem um olhar diferente sobre a história. O romance será interpretado sob a ideia de "narrativa performática". A análise será organizada com base em três eixos específicos: primeiro, a história contada pelos e desde os sujeitos minorizados; segundo, o corpo como agente que configura os acontecimentos narrados; e, por último, o recurso a imagem o ao gesto para posicionar o discurso histórico na esfera da imagem, o Amón na imagem, o texto é teatralizado, os discursos das personagens se tornam gestos e as múltiplas possibilidades interpretativas não só põem em diálogo o presente com o passado, mas também dão conta de uma pulsão pelo contemporâneo.

PALAVRAS-CHAVE: Romance histórico; literatura venezuelana performance; corpo.
O presente trabalho foi realizado com apoio da Coordenação de Aperfeiçoamento de Pessoal de Nível Superior - Brasil (CAPES) Código de Financiamento 001 


\section{LA HISTORIA CONTADA DESDE PRÁCTICAS}

\section{INESPECÍFICAS}

Tomando en cuenta que entre hoy y la primera parte del siglo XVII median casi cuatro siglos, a lo que se une la escasísima huella que de ese pasado nos queda, no parece posible aproximarse a una comprensión cabal de lo que fuera el imaginario cultural de la sociedad de entonces. Esta novela mira hacia aquellos venezolanos desde la representación que de ellos podemos tener hoy, con el propósito de concederle densidad narrativa a un pequeño, pero no por eso menos dramático fragmento de nuestro pasado (TORRES, 2013, p. 383).

El epígrafe que abre este trabajo es el último párrafo de La escribana del viento (2013), de Ana Teresa Torres. En él encuentro tres cuestiones que son vitales para una lectura de esta novela, pues a partir de ellas se redimensiona, lo que hasta ahora se ha conceptualizado como Novela histórica. En primer lugar, tenemos el vínculo - anacrónico - del "presente con el pasado", una discusión a partir de la cual vemos que la novela está atravesada por un cuestiona miento sobre lo contemporáneo. En segundo lugar, tenemos la idea de un "pequeño fragmento del pasado", que posiciona al texto en un lugar distinto al de la historiografía tradicional. Y, por último, "lo dra mático", a partir de lo cual, el texto de Torres nos presenta un funcionamiento teatral del texto narrativo. En este sentido, el objetivo que me planteo es a nalizar cómo el texto de Ana Teresa Torres pone en consona ncia el subgénero Novela Histórica con un repertorio de "prácticas inespecíficas" que involucran, el montaje, el cuerpo, la imagen, y el gesto, en el quehacer literario contemporáneo.

La escribana del viento se muestra como una invitación a leer la historia y la cultura venezolana desde un presente donde el yo es preponderante y su sentir está condicionado por la dinámica del poder; un yo que es resultado de una (macro, micro, bio, necro) política, lo cual supedita su discurso y su percepción. El texto revela así una pulsión de lo contemporáneo e intenta mirar, desde otros enfoques, cruzando líneas de pensa miento, a veces divergentes, para hacer visible aquello que pasó desapercibido: el gesto, la imagen, la emoción. La propuesta de Torres, devela un contacto con lo contemporáneo como resultado del esfuerzo por contar una historia desde otra perspectiva. En palabras de Alexis Márquez Rodríguez,

[..] el interés de Ana Teresa Torres por la historia como fuente de sus novelas no es casual ni caprichoso. Se trata, más bien, de un razonado y fundamental sentido de lo histórico como referencia del pasado, en función del presente y del futuro (RODRÍGUEZ, 2014, s.p.). 
Por esto, cuando pienso en La escribana como una novela histórica contemporánea, la asocio a la idea de Agamben que define lo contemporáneo como "una relación singular con el propio tiempo, que adhiere a éste, y a la vez, toma su distancia; más exacta mente, es esa relación con el tiempo que adhiere a este a través de un desfase y de un anacronismo [...]" (AGAMBEN, 2011, p. 18-19, énfasis del autor). De este modo, los acontecimientos de la novela, su estrategia narrativa y su montaje, se conectan con el presente a partir de la reiteración de algunas temáticas; así, esa mirada al pasado histórico, que Torres nos presenta, revela un conjunto de cuestiones inherentes al siglo XVII venezolano pero convoca, en simultáneo, a la mentalidad y al imaginario de nuestro presente; esto deviene en una tensión entre e mantener "la mirada fija en la oscuridad de la época [...]" (AGAMBEN, 2011, p. 23) y una búsqueda de respuestas en otros tiempos. Así pues, una perspectiva contemporánea implica un posicionamiento que "está en condiciones de transformarlo y ponerlo en relación con otros tiempos, de leer en él de manera inédita la historia, de 'citarla' según una necesidad [..]” (AGAMBEN, 2011, p. 28-29). Esta pulsión por lo contemporáneo dialoga con la propuesta de W Benjamin expresada en sus Tesis sobre la historia:

Cuando se pregunta con quién empatiza el historiador historicista. La respuesta resulta inevitable: con el vencedor. Y quienes dominan en cada caso son los herederos de todos aquellos que vencieron alguna vez. Por consiguiente, la empatía con el vencedor resulta en cada caso favorable para el dominador del momento. El materialista histórico tiene suficiente con esto. Todos aquellos que se hicieron de la victoria hasta nuestros días marchan en el cortejo triunfal de los dominadores de hoy, que avanza por encima de aquellos que hoy yacen en el suelo [...] todos deben su existencia no solo a la fatiga de los grandes genios que los crearon sino también a la servidumbre anónima de sus contemporáneos. [..] por eso el materialismo histórico se aparta de ella en la medida de lo posible. Mira como tarea suya la de cepillar la historia a contra pelo (BENJAMIN, 2008, p. 41-42).

En esta tesis, Benjamin, apunta a ese posicionamiento en el tiempo para revisar la historia recorriendo otros caminos, otras estrategias. Y es precisamente lo que hace Torres, se posiciona en el tiempo para recorrer un fragmento del pasado, por caminos intransitados hasta el momento. Su historia es una relectura, cada fragmento de la novela revitaliza los acontecimientos del pasado, cuenta la historia, pero - como bien lo dice Alexis Márquez Rodríguez - con una perspectiva desde el presente. Torres hace palpable la idea de Aga mben de leer de modo inédito la historia y citarla según la necesidad, y en simultáneo pone en escena la idea de Benjamin de "cepillar la historia a contra 
pelo". Todo apunta a mostrar que "la historia es objeto de una construcción cuyo lugar no es el tiempo homogéneo y vacío, sino el que está lleno de 'tiempos del ahoras' [...]" (BENJAMIN, 2008, p. 51). Los acontecimientos narrados en la novela son contados con una insistencia en lo corporal, en lo espacial, en lo perceptible, en lo cotidiano; este posiciona miento "hace saltar el continuum de la historia [...]" (BENJAMIN, 2008, p. 51). En otras palabras, la novela posiciona los acontecimientos en una tensión entre la dimensión histórica y una perspectiva de nuestros tiempos conecta el pasado con el presente a partir de acontecimientos que se mantienen vigentes en la actualidad, así pues, esa relectura de la historia que nos presenta Torres, es una relectura también de nuestro presente.

La escribana del viento es una novela sobre la huida, - y también sobre la pertenencia, esto se hace explícito con los epígrafes que inauguran cada apartado - que es el resultado de la injusticia y el abuso de poder del obispo Mauro del Toro, en contra de una familia de Caracas del siglo XVII. Los acontecimientos surgidos después de la llegada de esa figura eclesiástica marcaron la historia de Venezuela de ese siglo y después de esos eventos, en otras épocas, seguirán aconteciendo, y es sorprendente cómo esos hechos se renuevan con el pasar del tiempo. La historia se repite como una serpiente que se muerde la cola. Se repite el abuso de

EM TESE poder, la corrupción; se repite la ambición de gobernantes, las huidas y los desplazamientos forzosos y ta mbién los gestos, las emociones, el desprendimiento de aquello que creía mos propio. Todo esto se cuenta a partir de una escritura que apunta a desplazar las categorías tradicionales de la narrativa por estrategias estilísticas cercanas a las artes visuales, a la imagen, al teatro; de modo que estamos ante una manera de contar la historia que se configura a partir de "inespecificidades", que desestabilizan el estatuto de ficción; estamos en presencia de una literatura pos-autónoma. Como es explicado en el Indicionário do contemporâneo:

Post-autonomía implica, esencialmente, una disolución de las fronteras (o el reconocimiento de que ellas nunca existieron sino como la ficción necesaria para la sustentación del paradigma), entre géneros literarios, entre realidad y ficción, entre el adentro y el afuera del texto, entre la literatura y otras formas de expresión. Es la difuminación de los contornos con los cuales se delimita el dominio de la literatura (PEDROSA, 2018, p. 168, traducción mía). ${ }^{1}$

Así, ese carácter pos-autónomo en la novela de Torres, reconocida como una novela histórica, se revela a partir de la incorporación de un último apartado titulado "Testimonio de la autora" y que se conecta con los demás Testimonios que conforman la novela. Así como cada uno
. En el original: “Pós-autonomia implica, essencialmente, uma dissolução de fronteiras (ou o reconhecimento de que elas nunca existiram senão como a ficção necessária para a sustentaçăo do paradigma), entre generos literários, entre realidade e ficção, entre o dentro e o fora do texto, entre a literatura e outras formas de expressão. É o apagamento dos contornos com os quais se delimit o domínio da literatura." 
de los personajes elabora discursivamente su posición y su participación en los acontecimientos, a través de una escritura propia la autora cuenta también su proceso creativo su metodología, su trabajo, en fin, su experiencia de escritura, y así como los personajes cuentan su participación en la reconstrucción de la historia, ese apartado se estructura como un diario de trabajo en el que quedan registradas, las fuentes, los documentos y los procedimientos de escritura. Enfatizando en un posicionamiento al mismo tiempo dentro y fuera de la ficción. La incorporación de este último comentario muestra que está mostrando, exhibe su representación. Es un procedimiento a nálogo a la estética brechtiana. Recordemos la insistencia de Brecht, evidenciada sus textos (BRECHT, 1978), en hacer que los actores muestren siempre que están actuando, de la misma forma Torres hace explícito que está escribiendo relatando como la génesis y el proceso escritural de la novela:

Cuando muchos años atrás di, un tanto al azar, con Jimena de Ponte y Campos, no dudé que su vida constituye probablemente el primer caso documentado de una joven venezolana enjuiciada por un delito sexual que hoy veríamos como abuso [...] Me sentí conminada a apropiarla en una novela y emprendí el trabajo de documentación preliminar y la elaboración del primer guion” (TORRES, 2013, p. 377).
En otras palabras, mostrar que muestra o escribir que escribe "no es mentir sobre el estatus epistémico de la representación: es hacer de la imagen una cuestión de conocimiento y no de ilusión” (DIDI-HUBERMAN, 2008, p. 76). Una cuestión de conocimiento que como dijimos está en consonancia con el carácter post-autónomo de la literatura contemporánea y que desestabiliza el estatuto de ficción, a partir de la incorporación de prácticas inespecíficas, que están entre el tea tro y la narrativa, entre las artes visuales y la literatura, que se articulan, se montan y se desmontan a partir de estrategias performáticas.

\section{NECROPOLÍTICA: LA HISTORIA CONTADA DESDE EL}

\section{CUERPO}

La escribana del viento problematiza y pone en escena su montaje a partir de la diatriba entre la familia Navarro y Campos y el Obispo Mauro del Toro, representante de la iglesia católica, quien utiliza su poder en pro de su beneficio económico. Al llegar a Caracas en el siglo XVII (una ciudad llena de riquezas, pero todavía con aire de pueblo), la ambición del Obispo crece y se interesa de sobremanera por los bienes de una joven familia, Pedro de Ponte, Escribano mayor del Cabildo y Notario del Santo Oficio, y su esposa Beatriz. Este obispo, idea un plan en el cual, Pedro tiene que dejar como garantía todos los bienes; sin embargo, todas estas propriedades son en realidad de Beatriz. La 
mujer hace un documento de hipoteca, pero acto seguido hace otro documento que niega el anterior, imposibilitando que el obispo se quede con ellos, lo cual desata la furia de obispo e incrementa su codicia. Él asume la negación de Beatriz como una afrenta, por lo cual, aprovecha el poder que la Iglesia le otorga para emprender una serie de acusaciones contra toda la familia. Lo primero que el obispo hace es apresar a Beatriz y bajo tortura obtener testimonios forzados y algunos de ellos fabricados por él mismo, que comprometen a Pedro de Ponte. La acusación más grave y entorno a la cual se construye la propuesta narrativa es el hecho de mantener relaciones incestuosas con su hermana menor, Catalina de Campos, una adolescente quien es acusada, además del incesto, de abortar. El cuñado de Beatriz, Gabriel Navarro de Campos (de quien Beatriz quedó embarazada, por lo que también abortó) es asimismo acusado y perseguido por adulterio. De igual modo, acusó a la madre de todos ellos, Elvira de Campos, de no haber bautizado a sus siete hijos y de consentir el incesto entre los hermanos, del cual posiblemente Catalina quedó embarazada. Acusaciones similares fueron dirigidas a todos los personajes que tuviesen algún vínculo con la familia Navarro y Campos, incluso tres de las hermanas que eran monjas, murieron literalmente de ha mbre en el convento.
Estas situaciones llenas de injusticias revelan una forma sofisticada de lo que Achille Mbembe (2018) lla mó "necropoder". Este concepto explica la orga nización del estado moderno -apoyándose en los postulados de Michael Fouca ult - para reflexionar sobre el funcionamiento de la vida de los sujetos. Es decir, el acto y el ejercicio de dominación y la capacidad que tiene un sujeto de decidir quién vive y quién muere. Así, la soberanía se ejerce sobre el acto de matar y de castigar como es el caso del Obispo del Toro. La muerte condiciona en todo sentido a la existencia, entonces la modernidad se perfila en función de esa estrategia de poder, vinculada a la idea de la razón, la libertad y la civilización. Las sociedades instauran formas de gobierno que suprimen, controlan o a nulan las acciones de los hombres restringiendo su pensamiento, mutilando su raciocinio y transformando a los hombres en sólo cuerpos. Surge de este modo una "clausura biológica" que dio paso, según Mbembe, a una jerarquización que originó el racismo. La noción de necropolítica es útil para comprender las ideologías y la estética de la narrativa de Torres, la cual enfatiza la inclusión de lo corporal, al ca mpo textual y literario. En La escribana del viento encontramos representados los espacios de los silenciados. De este modo se muestra toda la dinámica de poder, se revela un gerenciar de las prácticas de los habitantes - el espacio se produce partiendo del habitar $-{ }^{2} \mathrm{y}$ del colectivo que condiciona su acción, lo cual implica

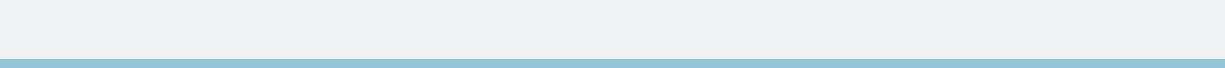
PÉREZ. Entre el gesto y la performance. Una lectura de La escribana del viento [...] P. 64-78
2. Henri Lefebvre, en su libro $L a$ producción del espacio señala
que el espacio es un producto queial y que se constituye fundamentalmente a partir de tres aspectos: en primer lugar, una práctica espacial, comprendida como el hacer cotidiano; en segundo lugar, existen unas representaciones del espacio, que se corresponden con todas las regularizaciones fundadas en la abstracción e impuestas sobre los usuarios que desarrollan ese hacer cotidiano, la práctica espacial; y, por último, existen unos espacios de representación, - como el arte y la literatura los cuales se caracterizan por configurarse a partir de una estrategia contrahegemonica. La práctica espacial se constituye por la relación entre el espacio miembro desarrolla en ese espacio es decir, se constituye a partir de una relación dialéctica que involucra un saber-hacer espacial (reglamentado, codificado) y una hacer propiamente dicho. Cada individuo produce el espacio social a traves "de una competencia y de 2013, p. 97). El producto de esto no es otra cosa que la vida cotidiana de los habitantes, de los usuarios. Este énfasis en lo espacial y en las prácticas cotidianas altera de forma significativa las modalidades representacionales, subvierte la relación que el hombre establece con su entorno dando paso a nuevas posibilidades discursivas $y$ representacionales. 
la negación de la vida y la clasificación de los seres, según su raza, su etnia, su género, su clase o su religión.

En otras palabras, los sentidos de soberanía, de libertad de vida y de muerte tienen un vínculo con lo corporal. La muerte da sentido a la vida, y la existencia se hace presente cuando el sujeto tiene dominio de su corporeidad, cuando su cuerpo (lo que hace con él, el trabajo, su sexualidad, su performance) no pertenece a otro, así la esclavitud es una especie de muerte. El sujeto esclavizado, los sujetos minorizados, o alguien cuya corporeidad represente lo abyecto, la minoridad, o la otredad, va a negársele la capacidad de pensar, de ser representado y de autorepresentarse. Las narrativas contemporáneas comienzan a darle voz a esos sujetos: ¿Qué acontece cuando lo que fue considerado abyecto enuncia? ¿Cómo son los discursos de los silenciados? Ante esas preguntas, vemos, a partir de La escribana del viento como las representaciones estarán atravesadas por una preponderancia de las prácticas incorporadas, donde destaca lo vivencial. Surge así una política de la memoria, que reafirma un cambio en los paradigmas y en las mentalidades. $\mathrm{E}$ foco de las representaciones ha cambiado, las modalidades discursivas y lo corporal, las prácticas cotidia nas, la imagen, el gesto, la performance marcaron la producción narrativa de los últimos tiempos. Las historias son performance porque los cuerpos tienen importancia, como dice Judith Butler (2010), y lo que se hace con ellos ta mbién.
Estas ideas sobre el cuerpo y la necropolítica explican el funcionamiento de la dinámica de poder en la novela de Torres. Todos los personajes sufren, son todos torturados con prácticas de la inquisición y todos se posicionan ante los acontecimientos, se reparten las culpas, y luchan en contra del abuso de poder, pero en el fondo cada uno tiene algo oculto que los demás no saben y es lo que queda siempre en duda. El ejemplo más revelador de esta estrategia narrativa es la acusación de Catalina y su huida la cual es parte fundamental del montaje de la novela, pues mantiene en tensión del rela to, produce un distanciamiento y al mismo tiempo una empatía, en consonancia con la estética de Brecht (1978), según la cual se debe "procurar al espectador una actitud analítica y critica frente al proceso representado [...]" (BRECHT, 1978, p. 132) que en el caso de La escribana del viento, es logrado a partir de la presentación de varias perspectivas sobre un mismo asunto, incluso contradictorias como lo vemos en relación al incesto del que es acusada Catalina, la protagonista, pues no queda claro si realmente aconteció o no. Todo esto se debe a las múltiples voces que construyen el rela to y cuyas perspectivas no siempre coinciden. Catalina revela que no está segura si el acto del incesto realmente aconteció, debido a que existen comentarios sobre la infertilidad de Pedro, por eso no tiene hijos con Beatriz; y la misma Catalina escribe: "[..] lo que ocurrió entre nosotros era una memoria turbia, como si yo 
lo estuviera viendo a través de un vidrio empañado que no deja saber la verdad de lo sucedido. A lo mejor solo fue un cruce de miradas [..] o mi imaginación aquella tarde al pie de la montaña” (TORRES, 2013, p. 297).

Así como este hecho, todo en la novela es turbio y dudoso, a veces los personajes despiertan empatía y otras veces rechazo. Lo único que parece tener certeza es el sufrimiento. Un sufrimiento que es corporal. Hay una reiteración al cuerpo violentado, del cuerpo que pecó, del cuerpo que abortó, de la tortura, una insistencia en mostrar cómo el espacio, la historia y los acontecimientos afectan al cuerpo, el sentir y la experiencia.

Por otro lado, la novela se construye a partir de testimonios individuales de cada uno de los personajes, quienes escriben en primera persona su experiencia. Cartas, testimonios, documentos oficiales de Los Archivos Históricos son intercalados para construir una visión caleidoscópica de los acontecimientos. El montaje de documentos se convierte en la estrategia para revelar la contemporaneidad de estos sucesos; la escritora recurre a la historia, subvierte las modalidades narrativas tradicionales y nos ofrece un discurso subjetivo - de cada uno de los personajes - pero no individual, pues desde lo menor y desde lo individual, - la historia de Catalina de Campos - se habla de la comunidad, de las comunidades, la vida familiar y las relaciones entre el poder eclesiástico y los miembros de la sociedad ca raqueña del siglo VXII, cuyos miembros forman parte de una clase y una raza naciente, los criollos, quienes difícilmente ejercían su soberanía. De modo que ese montaje de voces establece una lógica otra, una reorganización y un reparto que deshace y vuelve a rehacer. El montaje potencializa el énfasis en la minoridad y ofrece otras modalidades históricas:

el montaje posee ese "carácter destructor" por el que un modelo previo de relato - de temporalidad en general - se ve dislocado a fin de que se le extraiga la conflictividad inmanente, incluso la "raíz cuadrada", como expresa Benjamin jugando con las palabras. Por otra parte, el montaje procede desbrozando, es decir creando vacíos, suspenses [sic], intervalos que funcionarán como vías abiertas, caminos hacia una nueva manera de pensar la historia de los hombres y la disposición de las cosas (DIDI-HUBERMAN, 2008, p. 145).

El montaje, en la novela, disloca la historia, reinventa una posibilidad narrativa donde la temporalidad queda sujeta a las perspectivas y a las miradas individuales de los personajes dando paso a un diálogo entre subjetividades, entre emociones y gestos. Un diálogo entre el pasado y el presente, entre la realidad y la ficción. A partir de esta interacción metaficcional se construye un espacio biográfico 
(ARFUCH, 2007), autobiográfico e intra-histórico. Cada personaje habla de su experiencia, escribe su biografía, produciendo un texto que dialoga con los escritos de los demás personajes y con los demás documentos organizados por la autora. Cada trecho construye imágenes cerca nas a lenguaje teatral, cada testimonio parece un acto, un monólogo, incluso hay uno que reproduce un texto teatral, es el apartado de la novela, titulado "Confesión de Beatriz de Cepeda” (TORRES, 2013, p. 145-155), en el cual se muestra el interrogatorio que el Obispo le hace a Beatriz, se estructura justo como un libreto de una pieza de teatro:

Obispo: [..] Cuando doña Leonor presentó su demanda de divorcio, por supuesto que se la di enseguida. Saque las conclusiones. Ella tenía testigos de que su marido vivía con esta india en la hacienda, pero usted, ¿también los tiene para probar el adulterio de don Pedro? Si no hay testigos que declaren a su favor no puedo concederle lo que pide.

Beatriz: Las esclavas mismas.

Obispo: No me sirven a no ser que convengamos en algo. Beatriz: (silencio)

Obispo: Si alega que el motivo de la petición de separación conyugal es el incesto entre su marido don Pedro y su hermana doña Catalina, no le pediré testigos y la dejaré libre.
Beatriz: Estoy entregada a Dios.

Obispo: (al esclavo) Dale tres vueltas [...] (TORRES, 2013, p. 154).

Este caso extremo de teatralización de la novela - pues es explícito y evidente al usar la estructura de un texto teatral - va en consonancia con construcciones narrativas donde impera el gesto. De acuerdo con esto, en la novela opera el gesto, como dice Aga mbem, inscrito "en la esfera de la acción [..]" (AGAMBEN, 2001, p. 54). Pero se diferencia del actuar y del hacer - un hacer que, según Aga mbem interpretando a Aristóteles, es más cercano a la creación (poiesis) que a la praxis -, pues "La característica del gesto es que por medio de él no se produce ni se actúa, sino que se asume y se soporta [..]" (AGAMBEN, 2001, p. 54). Es decir, el soportar, disloca la acción y la lleva a un terreno donde la división entre los fines y los medios se difumina. Así, el gesto se configura como la "exhibición de una medialidad [..]” (AGAMBEN, 2001, p. 55, énfasis del autor). Es la expresión de aquello que no puede decirse ni expresarse en proposiciones.

\section{EL GESTO, LA PRESENCIA, LOS AFECTOS}

Entramos en la esfera de los afectos, el relato de Torres se ubica en esa esfera pues cada personaje expone, espectaculariza, pone en escena su dimensión afectiva y la historia 
se construye a partir de esos afectos, de esas emociones. La obra de Ana Teresa Torres en ese sentido, cristaliza la idea de mirar el mundo como una gran "historia patética" en la cual el pensador y el historiador debe asumir "como función política primera utilizar su memoria como advertencia de incendios futuros [..]" (DIDI-HUBERMAN, 2011 p. 195). En ese sentido, se pone en escena "la imaginación de sufrimientos futuros sobre la memoria de los sufrimientos padecidos [..]" (DIDI-HUBERMAN, 2011, p 195). En tanto, la memoria del gesto, instituye un posicionamiento en el tiempo y en simultáneo condiciona la mirada histórica de la novela haciendo explotar la dimensión heterocrónica del tiempo. En otras palabras, la insistencia en el uso de una memoria patética arrastra al texto hacia una construcción teatral, donde la imagen y lo visual son preponderantes, por lo cual, el gesto - entendido, memoria y materialización de las emociones - deviene en imágenes y las imágenes dialogan con la historia y lo contemporáneo. Todo esto nos muestra, como dice Didi-Huberman, que ante una imagen debemos reconocer "que probablemente ella nos sobrevivirá, que ante ella somos el elemento frágil, el elemento de paso y que ante nosotros ella es el elemento del futuro, el elemento de duración. La imagen a menudo tiene más memoria y más porvenir que el ser que la mira” (DIDI-HUBERMAN, 2011, p. 32).
Así, ese procedimiento de Ana Teresa Torres de contar la historia de Catalina de Campos y su enfrentamiento con el Obispo del Toro, de una manera fragmentaria, y titilante - subjetiva, sensible, enfa tizando en lo corporal, y construyendo a partir de imágenes y gestos un discurso narrativo-teatral - me hace pensar en la novela como una alegoría de la contemporaneidad, pues cada episodio trae consigo una formulación constante: "la alegoría interrumpe, suspende el desarrollo cronológico de la acción: observa en los intermedios del drama barroco donde surge un valor que Benjamin llama 'exegético' pero que seculariza la historia por su misma representación [..]” (DIDI-HUBERMAN, 2008, p. 188-189). Nuevamente, puedo leer en estas ideas sobre la alegoría una inmanencia política vinculada al afecto, es sin duda una expresión patética de la historia, no catártica, sino patéica, es un diálogo entre el presente y el pasado, gracias a la reiteración de las emociones.

En esta línea de ideas, me permitiré traer a colación un texto de Hans Urlish Gumbrecht pues, a partir de ese a utor puedo pensar que esa insistencia en lo corporal del texto de Torres, apunta también a redimensionar las posibilidades interpretativas del pasado y la comprensión del presente y de la historia. Gumbrecht cuestiona la hegemonía de la interpretación, en su texto explora y muestra las fisuras de la comprensión del pasado a partir de la idea exclusiva de 
3. En el original: “Quanto mais a autoimagem de determinada cultura corresponde à tipologia da cultura de sentido, mais ela tentara ocultar e ate excluir a violência como o mais avançado potencial de poder. Assim se pode explicar o fato de ter havido historiadores e filosofos da noss cultura que, nas décadas mais recentes, confundiram relações de poder com relações definidas pela distribuição do conhecimento." sujeto pensante, argumentando que existen otras posibilidades de contacto con los textos; encontramos en la novela de Torres esa posibilidad que la historia se piensa, se interpreta, se narra y también se siente. Torres nos muestra en su texto lo que Gumbrecht lla ma A produção da presença, como el atributo espacial de los objetos y del mundo en tanto son capaces de generar un efecto en el cuerpo.

Gumbrecht menciona la existencia de "culturas de sentido" (o de interpretación) regida por un condiciona miento temporal y una "cultura de presencia", en la cual predomina un componente espacial y corporal. En relación con esta clasificación, señala Gumbrecht, más adelante:

Cuando más la autoimagen de determinada cultura $\mathrm{co}^{-}$ rresponde a una tipología de la cultura de sentido, más ella intentará ocultar y hasta excluir la violencia como el más avanzado potencial de poder. Así, se puede explicar el hecho de haber tenido historiadores y filósofos de nuestra cultura que en las décadas más recientes, confundieron relaciones de poder con relaciones definidas por la distribución de conocimiento (GUMBRECHT, 2010, p. 110, traducción mía). ${ }^{3}$

A partir de esta afirmación y pensando en la insistencia de la violencia sobre el cuerpo tan reiterada en la novela, vemos como la propuesta de Torres se configura a partir de esta lógica. El pasado en la novela se reconstruye desde la producción de la presencia del cuerpo en el texto recurriendo a la exposición de la violencia, contruyendo la trama de la novela a partir de acontecimientos que giran en torno a la agresión del cuerpo. Además de formas interpretativas, cartas, testimonios, documentos, el contenido de cada uno de estos fragmentos expone formas no interpretativas que se encaminan a producir y a reproducir lo que Gumbrecht lla mó la presencia como forma de apropiación del mundo. En el caso de Torres es una forma de apropiación del pasado y una estrategia narrativa, ficcional y representacional de ponerlo en contacto con el presente. Es justamente esa idea la que despliega Torres en otro texto titulado El alma se hace de palabras: "No se vuelve al pasado para encontrarlo porque ya se ha desvanecido, se vuelve para darle sentido al presente [..]" (TORRES, 2003, p. 35). El presente y el pasado, así como la interpretación y la presencia se convierten en una "forma de ser accesible" (GUMBRECHT, 2010, p. 117), es una superación al miedo de ser leído, es una apertura voluntaria que se explicita con la vocación escritural y epistolar.

\section{DEL GESTO A LA PERFORMANCE}

Tanto el montaje de la novela como la producción de la presencia, revela un interés por incluir en su configuración 
prácticas incorporadas (gesto, imagen, teatro). Este procedimiento otorga un protagonismo a estas prácticas, que Diana Taylor lla mó el repertorio, en su libro $O$ arquivo e o repertório: Performance e memória cultural nas Américas. Este término dialoga e interactúa con la noción de archivo. Estos conceptos son desarrollados por Taylor para mostrar cómo la memoria se construye a partir de estrategias sistematizadas de documentos y preservación de nuestra memoria institucionalizadas como el archivo, pero también desde prácticas, en las cuales el cuerpo interviene en la transmisión de memorias y de conocimientos. Este es el repertorio, el cual se constituye a partir de los vestigios de las minoridades silenciadas o no oídas que comienzan a ser partícipes de El reparto de lo sensible, como dice Jacques Rancière, revelando así un vínculo entre la estética y la política y, en este caso, mostrando la dimensión política del gesto y de la imagen. Como vemos, la inclusión de este tipo de prácticas incorporadas, a la producción escritural de Torres, me permite hacer conexiones ta mbién con la performance, pues la novela como ya hemos dicho, al igual que la performance, da cuenta de actos, prácticas, objetos y procesos que se caracterizan por ser comporta mientos donde el cuerpo tiene una gran importancia. En ese sentido, la estética de Torres está en consonancia con la idea de performance, entendida como "actos de transferencia vitales, transmitiendo el

conocimiento, la memoria y un sentido de identidad social por medio de lo que Richard Schchener denomina 'comportamiento reiterado' [..]” (TAYLOR, 2013, p. 27, traducción mía). ${ }^{4}$

En esta línea de ideas, Graciela Ravetti nos habla de "narrativas performáticas" para referirse a este tipo de escritura. Nos dice que son

tipos específicos de textos escritos en los cuales ciertos trazos literarios comparten la naturaleza de la performance, recurriendo a la acepción de ese término en el ambiente escénico y en el político-social. Los aspectos que ambas nociones comparten, tanto a lo que se refiere a la teatralización (de cualquier signo) y a la agitación política, implican: la exposición radical de sí mismo, del sujeto enunciador así como del local de enunciación; la recuperación de comportamientos denunciados o recalcados; la exhibición de rituales íntimos la encarnación de situaciones de autobiografía; la representación de las identidades como un trabajo de restauración siempre inacabado (RAVETTI, 2002, p. 48, traducción mia).

La narrativa performática se inscribe en ese posicionamiento ante la historia que hemos comentado a partir de Benja mín y de Didi-Huberman. Asimismo, posiciona el cuerpo y en consecuencia la imagen y el gesto, como
4. En el original: "atos de transferência vitais, transmitindo o conhecimento, a memória e um sentido de identidade social por meio do que Richard Schechen reiterado' [..]".

5. En el original: "tipos específicos de textos escritos nos quais certos
traços literários compartilham a natureza da performance, recorrendo à acepção desse termo no ambiente cênico e no político-social. Os aspectos que ambas noções compartilham, tanto no que se refere à teatralização (de qualquer signo) e à agitação política, implicam: a exposição radical do si mesmo, do sujeito enunciador assim como do local da enunciação; a recuperação de comportamentos denunciados ou recalcados; a exibição de rituais intimos; a encarnação de situações da autobiografia; a representação das identidades como um trabalho de constante restauração, sempre inacabado". 
categorías que resignifican y reelaboran las maneras de contar la historia.

Por lo que debo resaltar como esa "teatralización de cualquier signo" en La escribana del viento, rige la representación del acto de escritura y de allí el tono personal de cada apartado, de cada carta, de cada testimonio. Las experiencias de los personajes son contadas, narradas por ellos mismos para cada personaje es una necesidad imperante narrativizar su experiencia de vida para preservar la memoria:

-Esto es para que escribas lo que te voy a dictar.

- ¿Una carta?

-Una larga carta, en efecto.

- ¿Para sor Isabel de Atienza?

-Para mi.

Nunca había escuchado que alguien se escribiera una carta a sí misma.

- ¿Y por qué escribir lo que ya se sabe?

-Para que no se me olvide, y a ti tampoco.

[...] Así fue que comencé a ser escribana

(TORRES, 2013 p. 34).
La trama está impregnada de un tinte subjetivo, desde el cual se construye el universo histórico y/o ficcional. De forma que se estructura una "realidaddeficción" (LUTMER, 2009), un relato entre la historia y la ficción; podemos pensar entonces la narrativa de Torres, sino como un montaje de autobiografías, al menos como un diálogo pseudoautobiográfico; ella no escribe biografías propiamente dichas, sin embargo, el texto preserva los rasgos vivenciales, subjetivos y construyen el espacio biográfico ${ }^{6}$ que resulta fundamental en la contemporaneidad porque en él surge un cuestiona miento y una jerarquización de los acontecimientos, de aquello que destaca y de aquello que merece ser representado.

\section{CONSIDERACIONES FINALES}

En La escribana, se exalta lo íntimo para enfatizar la enunciación subjetiva, la presencia del yo. La figura de la a utora no se compenetra del todo con la figura del personaje, como en una autobiografía, pero comparten ese ca mbio vivencial, emotivo, sobre el cual hemos insistido y que se presenta a través del gesto y de la imagen, de las vivencias. ¿El abuso de poder por parte de la iglesia siglo XVII no es, en esencia, el mismo que el de los gobernantes y los políticos de América Latina en la actualidad? ¿La huida de Catalina de Campos no es una alegoría a los millones de
6. El espacio biografico es pensado por Arfuch, a partir de Roland Barthes y Philippe Lejeune, como como expresión de la interiorida y afirmación de 'sí mismo' [...]" (ARFUCH, 2007, p.33) configurada a partir de modalidades discursivas - cartas, memorias, diarios etc. - “Esta costrucción narrativa de lo privado como esfera de la intimidad - contracara de un espacio público que se afirmaba a su vez en la doble dimensión de lo social y lo político - fue más allá de su configuración primigenia" (ARFUCH, 2007, p.34) pues narrar las vivencias revela un relacionamiento entre lo público y lo privado. 
refugiados, desplazados y exiliados que vaga n por el mundo reinventándose por causa de esa corrupción? ¿La problemática del aborto que es crucial en la novela no es acaso una problemática que todavía tiene al mundo revuelto y en enfrentamientos? ¿Ese fraccionamiento del texto y esa multiplicidad de voces y de perspectivas no tiene que ver con los susurros que nos rodean y que condicionan nuestras vivencias en la actualidad?

Estas preguntas, que son el sustento de la novela, atienden tanto a la historia narrada como a nuestro presente. Queda explícito a partir de ellas como la historia es heterocrónica y como la narrativa histórica se reinventa en función de atender las necesidades identitarias, culturales, discursivas, estéticas y políticas del presente.

\section{REFERENCIAS}

AGAMBEN, Giorgio. ¿Que é o contemporáneo?. In:

Desnudez. Trad. Cristina Sardoy. Buenos Aires: Adriana Hidalgo Editora, 2011. p. 17-29.

AGAMBEN, Giorgio. Notas sobre el gesto. In: Medios

$\sin$ fin. Notas sobre la política. Trad. Antonio Guimeno

Cuspinera. Valencia: Pretextos, 2001. p. 47-57.
ARFUCH, Leonor. El espacio biográfico. Dilemas de la subjetividad contemporánea. Buenos Aires: Fondo de

Cultura Económica, 2007.

\section{BENJAMIN, Walter. Tesis sobre la historia y otros}

fragmentos. Trad. Bolívar Echeverría, México D.F., Itaca: UNAM, 2008.

BRECHT, Bertolt. Estudos sobre teatro. Rio de Janeiro: Editora nova fronteira, 1978.

BUTLER, Judith. Cuerpos que importan. Sobre los límites materiales y discursivos del "sexo". Trad. Alcira Bixio.

Buenos Aires: Paidós, 2010

DIDI-HUBERMAN, Georges. Cuando las imágenes toman posición: El Ojo de la historia, 1. Trad. Inés Bértolo. Madrid: Antonio Machado Libros, 2008

DIDI-HUBERMAN, Georges. Ante el tiempo. Historia del arte y anacronismo de las imágenes. Trad. Antonio Oviedo. Buenos Aires, Adriana Hidalgo editora, 2011. 
GUMBRECHT, Hans. Produção de presença: o que o sentido não consegue transmitir. Trad. Ana Isabel Soares. Rio de Janeiro: Editora PUC-Rio, 2010.

LEFEBVRE, Henri. La producción del espacio. Trad. Emilio Martínez. Barcelona: Capitan Swing, 2013.

LUTMER, Josefina. Literaturas postautónomas 2.0 Propuesta educativa, n. 32, p. 41-42, 2009.Facultad Latinoamericana de Ciencias Sociales Buenos Aires, Argentina Disponible en: http://www.redalyc.org/articulo oa? id=403041704005. Consultado el día 28 de enero de 2019.

MEMBE, Achielle. Necropolítica: biopoder, soberania e estado de exceção. Trad. Renata Santinni. São Paulo: n-1 ediçoes, 2018.

PEDROSA, Célia et al (Orgs.). Indicionário do contemporâneo. Belo Horizonte: Editora UFMG, 2018.

RANCIÈRE, Jaques. El reparto de lo sensible. Trad. Cristóba Durán. Santiago de Chile: LOM, 2009.
RAVETTI, Graciela. Narrativas performáticas. In: RAVETTI, G.; ARBEX, M. (Orgs.). Performance, exílio, fronteiras errâncias territoriais e textuais. Belo Horizonte: Pós-Lit UFMG, 2002. p. 48-67.

RODRIGUEZ, Alexis. La escribana del viento. El Nacional Caracas, 02 de febrero de 2014. Disponible en: http:// www.el-nacional.com/noticias/historico/escribana-delviento 93650. Consultado el día 31 de julho de 2019.

TAYLOR, Diana. $\mathbf{O}$ arquivo e o repertório: Performance e memória cultural nas Américas. Trad. Eliana Lourenço de lima Reis. Belo Horizonte: Editoria UFMG, 2013.

TORRES, Ana Teresa. La escribana del viento. Caracas: Editorial Alfa, 2013.

TORRES, Ana Teresa. El alma se hace de palabras. Caracas: Editorial Blanca Patín, 2003.

Recebido em: 23-08-2019. Aceito em: 10-12-2019. 